\title{
Effect of Dietary Calcium on Metabolic Balance of Normal Infants
}

\author{
BASILIO DEVIZIA,' SAMUEL J. FOMON, STEVEN E. NELSON, BARBARA E. EDWARDS, AND \\ EKHARD E. ZIEGLER
}

Department of Pediatrics, The University of Iowa, Iowa City, Iowa 52242

\begin{abstract}
Metabolic balance studies were performed with six normal infants fed in a balanced cross $-0 v e r$ design three formulas differing only in calcium concentration: 389 , 659 , and $1024 \mathrm{mg} /$ liter. Absorption of phosphorus was significantly affected by increasing calcium intake decreasing from 68 to 63 to $52 \%$ of intake. However, since urinary excretion of phosphorus also decreased, there was no significant effect on retention of phosphorus. Absorption of fat was slightly (but significantly) depressed by calcium, decreasing from 97.5 to 95.5 to $92.1 \%$ as calcium intake increased. The level of dietary calcium had no significant effect on absorption or retention of nitrogen, magnesium, copper, and zinc. One of the subjects had consistently lower absorption of calcium and fat than the other subjects, suggesting an absorptive defect. The decrease in fractional absorption of calcium (57 to 47 to $39 \%$ of intake) with increasing intake of calcium is compatible with adaptive regulation. On the other hand, the observation that absorbed calcium $(\mathrm{mg} / \mathrm{kg} / \mathrm{day})$ was linearly related to intake of calcium with a slope of 0.373 suggests an alternative explanation: constant passive, concentration-dependent (slope), and constant active ( $y$-intercept) transport of calcium over the range of calcium intakes. Thus, the findings are explainable in more than one way and do not necessarily demonstrate regulatory changes. (Pediatr Res 19: 800806, 1985)
\end{abstract}

\author{
Abbreviations \\ MCa, intermediate calcium \\ LCa, low calcium \\ HCa, high calcium
}

intake of calcium, but not depressed by high intake $(1,24)$. In the normal human infant systematic studies of the effect of varying dietary intakes of calcium on the absorption of other nutrients are lacking. The study reported herein was undertaken to provide such data.

A further goal of the present study was to examine the effect of varying levels of calcium intake on absorption of calcium and on other parameters of calcium balance. Low dietary intake of calcium leads to increased fractional absorption (i.e. absorption expressed as percent of intake), whereas high intake is associated with low fractional absorption. This adaptive response has been demonstrated in various animal species $(4,25-34)$ as well as in adult man $(24,35,36)$, but not in infants. It involves the active, saturable component of calcium absorption $(27,32)$ and is vitamin $\mathrm{D}$ dependent $(25,37)$. We hypothesized that in infants fractional absorption of calcium would be less at high than at low calcium intake.

Balance studies were performed with three specially prepared formulas similar in composition except for calcium content, which ranged from about 400 to $1000 \mathrm{mg} /$ liter, i.e. from a calcium concentration somewhat greater than that of human milk to a concentration approaching that of whole cow milk. The formulas were based on soy protein isolate because of the ease with which mineral content of soy formulas can be modified.

\section{SUBJECTS}

Six normal Caucasian infants (one female and five males) who weighed more than $2500 \mathrm{~g}$ at birth served as subjects. They were admitted to the Lora N. Thomas Metabolic Unit for balance studies, usually at intervals of $2 \mathrm{wk}$. The study was approved by the University of Iowa Committee on Research Involving $\mathrm{Hu}$ man Subjects. Before enrollment one or both parents visited the unit to observe procedures involved. The purpose of the study and the procedures were explained in detail and written consent was obtained. In our unit infants are enrolled during the first weeks of life and usually participate in several studies in sequence. Before participating in the present study, all but two subjects (2492 and 2493) had participated in other studies. All had been fed since birth commercially prepared formulas or formulas with similar $\mathrm{Ca}$ and $\mathrm{P}$ content and providing $400 \mathrm{IU} /$ liter of vitamin $\mathrm{D}$. If subjects became ill during the days before a scheduled balance study, the study was cancelled; if they became ill during a study, it was discontinued. In either case the study was then rescheduled $2 \mathrm{wk}$ after the original date. Illness of the infant and, in the case of subject 2493, staff vacation, increased intervals between some studies. As may be seen from Figure 1, the infants ranged in age from 22 to 367 days.

\section{STUDY DESIGN}

The basic design is evident from Figure 1. Each subject had two balance studies with each of the three formulas. A repeated 


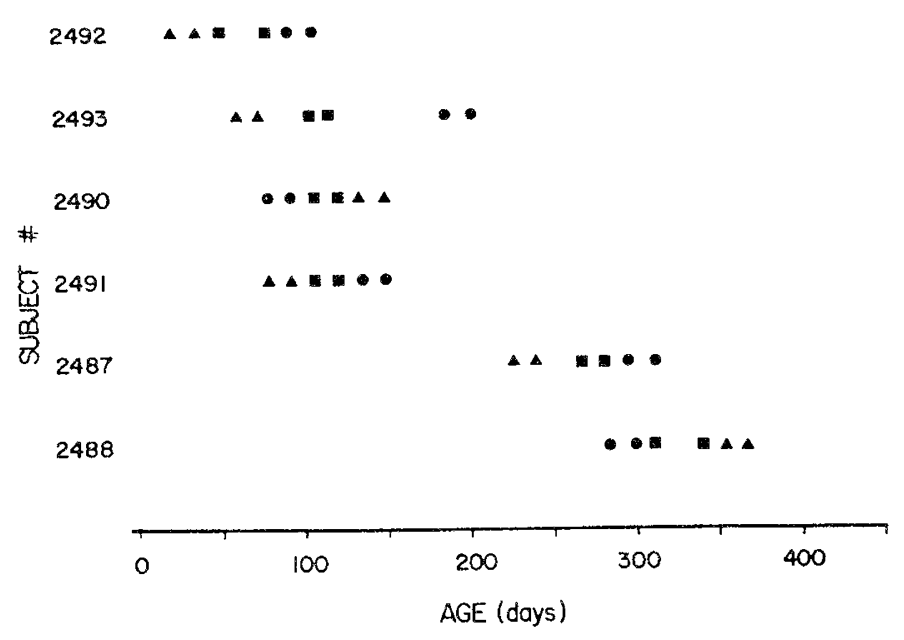

Fig. 1. Age of study subjects. balance study with formula LCa; formula $\mathrm{MCa} ; \mathrm{\Lambda}$, formula $\mathrm{HCa}$

measures design was used, where the formula formula $\mathrm{MCa}$ was always studied between studies of the other formulas. One-half of subjects were to be studied initially while being fed formula $\mathrm{LCa}$ and one-half while being fed formula HCa. However, in the case of subject 2493 the two initial balance studies with formula $\mathrm{LCa}$ had to be cancelled due to illness. By oversight, the infant was then fed formula $\mathrm{HCa}$ and had the first balance study 11 days later. Thus, four of the six infants were first studied with formula $\mathrm{HCa}$ and two with formula $\mathrm{LCa}$.

\section{FEEDINGS}

The three formulas were of nearly identical composition (Table 1), except for source and concentration of calcium and for source of phosphorus. Each was prepared in one batch by Ross Laboratories, Columbus, $\mathrm{OH}$. The formulas were supplied in readyto-feed form in quart cans. All three formulas were prepared from soy protein isolate with lactose as the carbohydrate and coconut and soy oils as the fat. With the exception of calcium and phosphorus, minerals were provided from identical sources and were present in nearly identical concentrations. Four salts of calcium were used in different combinations (Table 1) to achieve the desired calcium concentrations of about 400, 700, and $1000 \mathrm{mg} /$ liter respectively, and phosphorus concentration of about $500 \mathrm{mg} /$ liter. As is evident from table 1, actual concentrations of $\mathrm{Ca}$ and $\mathrm{P}$ were within $6 \%$ of these target concentrations.

A particular formula was fed for at least 11 days before the first balance study was performed and, consequently, was fed for at least 25 days before the second balance study. Cancellations of studies led to longer periods of feeding before some balance studies. Fortuitously, this occurred only with formula $\mathrm{MCa}$, which was fed for 25 days before two of the first balance studies and for 39 days before four of the second balance studies.

Whereas infants less than 120 days of age received no foods other than formula, modest amounts of commercially prepared cereals, fruits and vegetables from one manufacturer (Gerber Products Co., Fremont, MI) were permitted beyond that age. These foods, selected for their low content of calcium and phosphorus, provided no more than $8 \%$ of calcium intake and $13 \%$ of phosphorus intake during individual balance studies.

\section{METHODS}

Metabolic balance studies of $72 \mathrm{~h}$ duration were carried out in the manner previously described (38). Intake of nutrients was calculated from the weighed intake of foods and the determined nutrient concentrations. Net absorption was calculated as intake minus fecal excretion, and net retention was calculated as intake
Table 1. Composition of feedings*

\begin{tabular}{lccc}
\hline & \multicolumn{3}{c}{ Formula } \\
\cline { 2 - 4 } & $\mathrm{LCa}$ & $\mathrm{MCa}$ & $\mathrm{HCa}$ \\
\hline Energy (kcal/dl) & 67 & 67 & 67 \\
Major constituents $\dagger(\mathrm{g} / \mathrm{dl})$ & & & \\
$\quad$ Protein $\ddagger$ & 2.01 & 2.00 & 1.99 \\
Fat $\$$ & 3.52 & 3.60 & 3.55 \\
Carbohydrate\| & 6.68 & 6.71 & 6.64 \\
Mineralsf (per liter) & & & \\
Calcium (mg) & $389^{* *}$ & $659 \dagger \dagger$ & $1024 \ddagger \ddagger$ \\
Phosphorus (mg) & $485 \S \S$ & $477 \S \S$ & $520 \S \S$ \\
Magnesium (mg) & 52 & 55 & 59 \\
Sodium (mEq) & 14 & 14 & 14 \\
Chloride (mEq) & 15 & 15 & 16 \\
Potassium (mEq) & 26 & 27 & 22 \\
Iron (mg) & 17.1 & 16.5 & 13.1 \\
Zinc (mg) & 6.04 & 5.94 & 5.27 \\
Copper (m) & 0.79 & 0.78 & 0.74 \\
Manganese (mg) & 0.44 & 0.45 & 0.35 \\
Iodine (mg) & 0.15 & 0.15 & 0.15 \\
\hline
\end{tabular}

* Each formula contained the following vitamins added per liter: vitamin A, $2500 \mathrm{IU}$; cholecalciferol, $400 \mathrm{IU}$; vitamin E, $15 \mathrm{IU}$; vitamin $\mathrm{K}_{1}, 0.15 \mathrm{mg}$; vitamin $\mathrm{C}, 55 \mathrm{mg}$; vitamin $\mathrm{B}_{1}, 0.4 \mathrm{mg}$; vitamin $\mathrm{B}_{2}, 0.6 \mathrm{mg}$; niacin equiv. $9.0 \mathrm{mg}$; vitamin $\mathrm{B}_{6}, 0.4 \mathrm{mg}$; pantothenic acid, $5.0 \mathrm{mg}$; folic acid, $0.1 \mathrm{mg}$; vitamin $\mathrm{B}_{12}, 3.0 \mu \mathrm{g}$; biotin, $0.15 \mathrm{mg}$. Minerals added: $\mathrm{K}$ citrate, $\mathrm{KCl}, \mathrm{MgCl}_{2}, \mathrm{NaCl}, \mathrm{FeSO}_{4}, \mathrm{ZnSO}_{4}, \mathrm{CuSO}_{4}, \mathrm{MnSO}_{4}, \mathrm{KI}$.

$\dagger$ Manufacturer's analysis.

$\ddagger$ Soy protein isolate (Edi-Pro A, Ralston Purina Co., St. Louis, MO) with $\mathrm{L}$-methionine $(16.3 \mathrm{mg} / \mathrm{dl})$.

$\S$ Coconut oil $(60 \%)$ and soy oil $(40 \%)$.

|| Lactose.

I Author's analysis except for iodine, which is amount added.

** From $\mathrm{CaHPO}_{4}(88 \%)$ and $\mathrm{Ca}\left(\mathrm{H}_{2} \mathrm{PO}_{4}\right)_{2} \cdot \mathrm{H}_{2} \mathrm{O}(12 \%)$.

†† From $\mathrm{CaHPO}_{4}(46 \%), \mathrm{CaCO}_{3}(46 \%)$ and $\mathrm{Ca}\left(\mathrm{H}_{2} \mathrm{PO}_{4}\right) \cdot \mathrm{H}_{2} \mathrm{O}(8 \%)$.

林 From $\mathrm{Ca}_{3}\left(\mathrm{PO}_{4}\right)_{2}(62 \%)$ and $\mathrm{CaCO}_{3}(38 \%)$.

$\S \S$ Includes approximately $90 \mathrm{mg} /$ liter as phytate-phosphorus from soy protein isolate.

minus total (fecal plus urinary) excretion. Glassware used for collection and storage of feces and urine was machine washed, then immersed in $3 \mathrm{~N}$ nitric acid, and rinsed with deionized water. During balance studies, feces and urine were kept at $4^{\circ} \mathrm{C}$, and care was taken to avoid contamination with trace minerals. The entire fecal collection was weighed and homogenized with a Teflon blade and a weighed amount was removed for trace mineral analysis. A $10 \%$ (by weight) aliquot of the homogenate was removed, acidified with $1 \mathrm{ml}$ concentrated $\mathrm{HCl}$ and made into a slurry by adding deionized water to a volume of $200 \mathrm{ml}$. The slurry was stored at room temperature until analyzed. Volume of the 72-h urine collection was determined. A portion was removed and stored at $4^{\circ} \mathrm{C}$ in plastic bottles for trace mineral analysis. Another portion was acidified with concentrated $\mathrm{HCl}$ and stored in glass bottles at room temperature until analyzed.

All determinations were performed in duplicate and results were averaged. In the case of formula and other foods, each of three samples were analyzed in duplicate.

In feces, fat was analyzed by the method of Van de Kamer et al. (39), and nitrogen by the micro-Kjeldahl method, as described previously (40). For determination of $\mathrm{Ca}, \mathrm{Mg}$, and $\mathrm{P}$, food and feces (slurry) were dried at $100^{\circ} \mathrm{C}$, ashed at $540^{\circ} \mathrm{C}$ overnight, and ashes dissolved in dilute $\mathrm{HCl}$. Urine was analyzed without ashing. Calcium and magnesium were determined by atomic absorption spectrophotometry (Perkin-Elmer model 303). Phosphorus was determined by a minor modification of the method of Fiske and Subbarow (41).

For copper and zinc determinations, samples of food and feces were placed in porcelain crucibles, dried at $100^{\circ} \mathrm{C}$, ashed for 12 h at $400^{\circ} \mathrm{C}$, and ashes dissolved in $\mathrm{N}$ nitric acid. Urine was 
analyzed without ashing. Determinations were made by atomic absorption spectrophotometry using a Perkin-Elmer model 303 in the case of zinc and a Perkin-Elmer model 306 with HGA 2100 graphite furnace in the case of copper.

\section{DATA ANALYSIS}

General linear models procedures utilizing a factorial repeated measures design were used to perform analysis of variance. Since most parameters of nutrient balance are influenced by the intake of the nutrient in question, correction to the common mean intake (analysis of covariance) was applied. This procedure was used to correct for variation in intake of nutrients caused by differences in amount of formula consumed and by differences in types and amounts of other foods consumed. Because calcium intake was experimentally manipulated, correction for intake was made to the formula mean intake, rather than the common mean intake. Use of corrected values was restricted to statistical evaluation. Thus, values appearing in the tables and figures are uncorrected for intake. When the $F$ test indicated a statistically significant $(p<0.05)$ main effect (e.g. of formula), Bonferroni $t$ tests were used to assess the differences between main effect means (i.e. between individual formulas). Other statistical methods are mentioned in the "Results" section.

Inspection of the data indicated that there was no difference between studies performed before and those performed after the studies with formula MCa. However, it was apparent that for some nutrients there were differences between results of the first and the second studies with the same formula (see "Results"). Therefore, an "order" term was incorporated in the analysis of variance procedure.

\section{RESULTS}

Phosphorus. As is evident from Table 2, with increasing calcium content of the formula fecal excretion of phosphorus increased significantly $(p<0.01)$ and consequently absorption of phosphorus decreased significantly, whether expressed in absolute terms $(p<0.01)$ or as a percentage of intake $(p<0.001)$. Fecal excretions of phosphorus and of calcium were strongly correlated $(r=0.921, p<0.001)$. As phosphorus absorption decreased with increasing calcium intake, so did urinary excretion of phosphorus $(p<0.01)$. Thus, despite the decrease in phosphorus absorption, there was no decrease in phosphorus retention. Significance levels refer to the F test. With some minor exceptions, pairwise comparisons between formulas (Bonferroni $t$ test) were also significant where the $F$ test showed overall statistical significance. Linear regression analysis of individual values showed that whereas absorption of calcium and phospho-

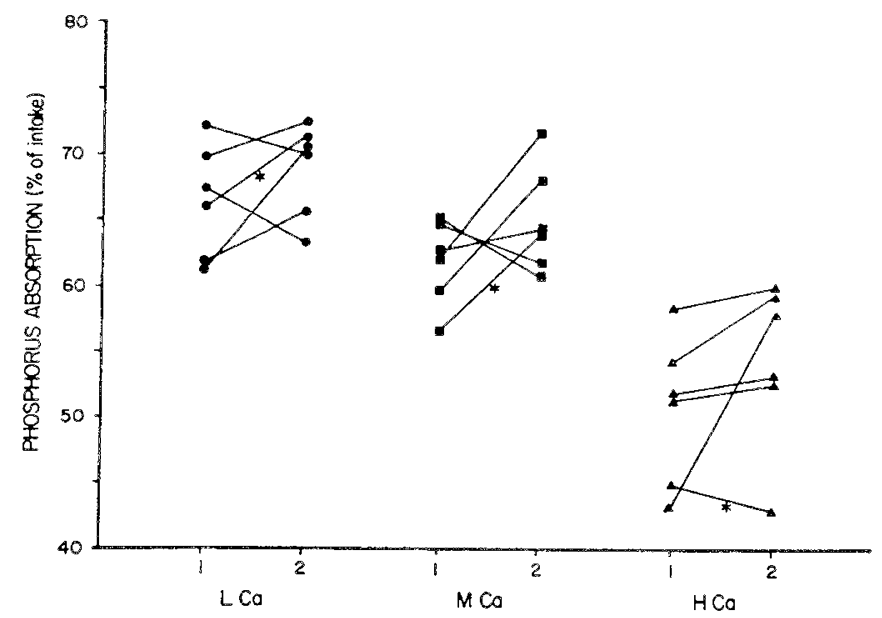

Fig. 2. Fractional absorption of phosphorus. Results of individual balance studies wih the same infant are connected by lines. Results for subject 2492 are indicated by an asterisk.

Table 2. Summary of data for calcium, phosphorus, and magnesium ${ }^{*} \dagger$

\begin{tabular}{|c|c|c|c|c|c|c|c|}
\hline & \multicolumn{2}{|c|}{ Formula LCa } & \multicolumn{2}{|c|}{ Formula MCa } & \multicolumn{2}{|c|}{ Formula $\mathrm{HCa}$} & \multirow[b]{2}{*}{$p+$} \\
\hline & Mean & $\overline{S D}$ & Mean & $\mathrm{SD}$ & Mean & $\mathrm{SD}$ & \\
\hline \multicolumn{8}{|l|}{ Calcium } \\
\hline Intake (mg/kg/day) & 65 & 14 & 117 & 28 & 176 & 42 & \\
\hline Fecal excretion (mg/kg/day) & $28^{a}$ & 10 & $62^{\mathrm{b}}$ & 23 & $109^{c}$ & 39 & $<0.001$ \\
\hline Urinary excretion $(\mathrm{mg} / \mathrm{kg} /$ day $)$ & $2^{\mathrm{a}}$ & 1 & $2^{\mathrm{a}}$ & 2 & $4^{b}$ & 2 & $<0.01$ \\
\hline Absorption (mg/kg/day) & $37^{\mathrm{a}}$ & 10 & $55^{\mathrm{b}}$ & 18 & $67^{\circ}$ & 20 & $<0.001$ \\
\hline ( $\%$ of intake) & $57^{\mathrm{a}}$ & 10 & $47^{\mathrm{b}}$ & 11 & $39^{\circ}$ & 10 & $<0.001$ \\
\hline Retention (mg/kg/day) & $35^{\mathrm{a}}$ & 10 & $53^{\mathrm{b}}$ & 19 & $64^{b}$ & 21 & $<0.001$ \\
\hline (\% of intake) & $54^{\mathrm{a}}$ & 10 & $45^{\mathrm{b}}$ & 11 & $37^{c}$ & 10 & $<0.001$ \\
\hline \multicolumn{8}{|l|}{ Phosphorus } \\
\hline Intake (mg/kg/day) & 82 & 17 & 86 & 20 & 91 & 21 & \\
\hline Fecal excretion (mg $/ \mathrm{kg} /$ day) & $26^{\mathrm{a}}$ & 6 & $32^{\mathrm{a}}$ & 8 & $44^{\mathrm{b}}$ & 14 & $<0.01$ \\
\hline Urinary excretion $(\mathrm{mg} / \mathrm{kg} / \mathrm{day})$ & $25^{\mathrm{a}}$ & 6 & $18^{\mathrm{b}}$ & 4 & $9^{c}$ & 3 & $<0.01$ \\
\hline Absorption (mg/kg/day) & $56^{\mathrm{a}}$ & 12 & $54^{2}$ & 13 & $47^{\mathrm{b}}$ & 8 & $<0.01$ \\
\hline ( $\%$ of intake) & $68^{\mathrm{a}}$ & 4 & $63^{\mathrm{a}}$ & 4 & $52^{\mathrm{b}}$ & 6 & $<0.001$ \\
\hline Retention (mg/kg/day) & 30 & 11 & 37 & 12 & 38 & 9 & NS \\
\hline (\% of intake) & 36 & 9 & 42 & 7 & 42 & 6 & NS \\
\hline \multicolumn{8}{|l|}{ Magnesium } \\
\hline Intake $(\mathrm{mg} / \mathrm{kg} /$ day $)$ & 9.6 & 1.8 & 10.5 & 1.8 & 10.9 & 2.2 & \\
\hline Fecal excretion (mg/kg/day) & $5.1^{\mathrm{a}}$ & 1.3 & $5.4^{\mathrm{a}}$ & 1.7 & $5.4^{\mathrm{b}}$ & 2.1 & NS \\
\hline Urinary excretion (mg/kg/day) & 3.4 & 0.9 & 3.3 & 1.4 & 3.7 & 1.2 & NS \\
\hline Absorption $(\mathrm{mg} / \mathrm{kg} /$ day $)$ & $4.4^{\mathrm{a}}$ & 1.3 & $5.1^{\mathrm{a}}$ & 1.8 & $5.6^{\mathrm{b}}$ & 1.6 & NS \\
\hline (\% of intake) & 46 & 8 & 48 & 14 & 52 & 12 & NS \\
\hline Retention (mg/kg/day) & 1.0 & 0.8 & 1.7 & 1.3 & 1.9 & 0.9 & NS \\
\hline (\% of intake) & 10 & 10 & 15 & 13 & 17 & 6 & NS \\
\hline
\end{tabular}

* There were 12 balance studies with each formula.

$\uparrow$ Values on same line with different superscripts are significantly $(p<0.05)$ different (Bonferroni $t$ test).

$\ddagger F$ test. 
rus were not significantly related $(r=0.313)$, retention of calcium and phosphorus were strongly related $(r=0.749, p<0.001)$.

Individual values for fractional absorption of phosphorus are presented in Figure 2. Fractional absorption was higher $(p<$ 0.04 ) during second than during first balances; however, the order effect was not statistically significant for any other parameter of phosphorus balance. Values for subject 2492 were not different from those for the other subjects.

Other nutrients. Because fecal excretion of magnesium remained practically constant despite slightly greater intakes of magnesium from formulas $\mathrm{MCa}$ and $\mathrm{HCa}$ than from formula $\mathrm{LCa}$, net absorption of magnesium increased slightly with increasing calcium intake (Table 2). The increase was of questionable statistical significance: absorption with $\mathrm{HCa}$ was greater than with $\mathrm{LCa}(p<0.05)$, but the overall effect (F test) was not statistically significant. There was no order effect and data for subject 2492 were not different from data for the other five subjects.

As indicated in Table 3, mean intakes of copper and zinc were similar with the three formulas. Mean fecal excretions were nearly equal to intakes. No significant differences due to different intakes of calcium were noted in any of the parameters of copper and zinc balance. Only small amounts of copper and zinc were excreted in the urine and data have therefore not been included in Table 3. There was no order effect and data for subject 2492 were not noticeably different from data for the other subjects.

Only minor differences between formulas were noted in parameters of nitrogen balance (Table 3 ). There was no order effect for urinary excretion or retention of nitrogen, but a significant $(p<0.02)$ order effect was present for fecal excretion and absorption, both absolute and fractional.

Absorption of fat (percentage of intake) decreased significantly $(p<0.01, \mathrm{~F}$ test) with increasing intake of calcium (Table 3$)$. The difference between formulas LCa and MCa was not significant, but fat absorption from formula $\mathrm{HCa}$ was significantly ( $p$ $<0.05$ ) less than from formula LCa. there was no order effect. However, subject 2492 absorbed fat significantly $(p<0.01)$ less efficiently than did the other subjects. Fecal excretion of calcium was significantly correlated $(r=0.807, p<0.001)$ with fecal excretion of fat.

Calcium. As indicated in Table 2, mean intake of calcium was
$65 \mathrm{mg} / \mathrm{kg} /$ day with formula LCa, $117 \mathrm{mg} / \mathrm{kg} /$ day with formula $\mathrm{MCa}$, and $176 \mathrm{mg} / \mathrm{kg} /$ day with formula $\mathrm{HCa}$. With greater intakes of calcium, fecal excretion of calcium increased significantly $(p<0.001, \mathrm{~F}$ test $)$ but to a lesser degree than intake; thus, absorption of calcium $(\mathrm{mg} / \mathrm{kg} /$ day) also rose significantly. Fractional absorption of calcium decreased significantly $(p<0.001)$ with increasing intake, averaging $57 \%$ with $\mathrm{LCa}, 47 \%$ with $\mathrm{MCa}$, and $39 \%$ with $\mathrm{HCa}$. Urinary excretion of calcium increased significantly $(p<0.01)$ with increasing intake of calcium but because urinary excretion was very low at any intake, retention of calcium behaved in nearly the same manner as absorption: absolute retention increased and fractional retention decreased significantly with increasing calcium intake. Significance levels refer to the $\mathrm{F}$ test. Bonferroni $t$ tests demonstrated significant differences ( $p<0.05$ or less) between formulas in every case except for urinary excretion between formulas $\mathrm{LCa}$ and $\mathrm{MCa}$.

Individual values for fractional calcium absorption are presented in Figure 3. In addition to the decrease in fractional

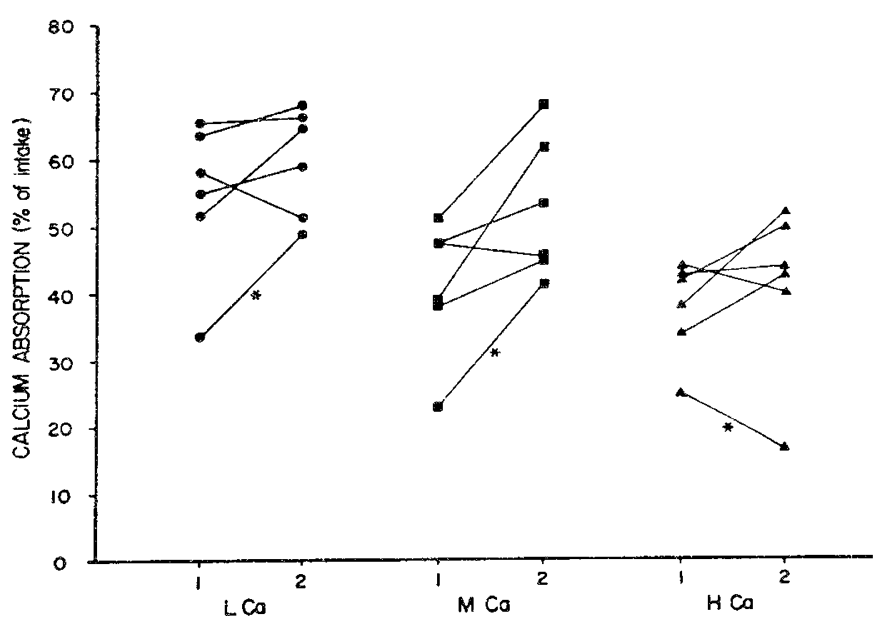

Fig. 3. Fractional absorption of calcium. Results of individual balance studies with the same infant are connected by lines. Results for subject 2492 are indicated by an asterisk.

Table 3. Summary of data for copper, zinc, nitrogen, and fat ${ }^{*,} \dagger$

\begin{tabular}{|c|c|c|c|c|c|c|c|}
\hline & \multicolumn{2}{|c|}{ Formula LCa } & \multicolumn{2}{|c|}{ Formula $\mathrm{MCa}$} & \multicolumn{2}{|c|}{ Formula $\mathrm{HCa}$} & \multirow[b]{2}{*}{$p \ddagger$} \\
\hline & Mean & $\mathrm{SD}$ & Mean & $\mathrm{SD}$ & Mean & $\mathrm{SD}$ & \\
\hline \multicolumn{8}{|l|}{ Copper } \\
\hline Intake $(\mu \mathrm{g} / \mathrm{kg} /$ day $)$ & 134 & 28 & 142 & 29 & 131 & 28 & \\
\hline Fecal excretion $(\mu \mathrm{g} / \mathrm{kg} /$ day $)$ & 132 & 25 & 135 & 32 & 134 & 31 & NS \\
\hline Absorption ( $\%$ of intake) & 1 & 9 & 5 & 10 & -2 & 5 & NS \\
\hline \multicolumn{8}{|l|}{ Zinc } \\
\hline Intake $(\mathrm{mg} / \mathrm{kg} /$ day $)$ & 1.02 & 0.22 & 1.07 & 0.25 & 0.92 & 0.21 & \\
\hline Fecal excretion (mg/kg/day) & 1.04 & 0.24 & 1.03 & 0.20 & 0.95 & 0.24 & NS \\
\hline Absorption ( $\%$ of intake) & -3 & 10 & 2 & 11 & -2 & 9 & NS \\
\hline \multicolumn{8}{|l|}{ Nitrogen } \\
\hline Intake (mg/kg/day) & 549 & 114 & 580 & 129 & 560 & 124 & \\
\hline $\begin{array}{l}\text { Absorption }(\mathrm{mg} / \mathrm{kg} / \text { day }) \\
\text { (\% of intake) }\end{array}$ & 449 & 95 & 476 & 107 & 444 & 113 & NS \\
\hline $\begin{array}{l}\text { (\% of intake) } \\
\text { Urinary excretion }(\mathrm{mg} / \mathrm{kg} / \text { day })\end{array}$ & 82 & 2 & 82 & 2 & 79 & 7 & NS \\
\hline Urinary excretion $(\mathrm{mg} / \mathrm{kg} /$ day $)$ & 277 & 35 & 276 & 42 & 259 & 53 & NS \\
\hline Retention $(\mathrm{mg} / \mathrm{kg} /$ day) & 172 & 89 & 200 & 95 & 185 & 97 & NS \\
\hline$(\%$ of intake) & 30 & 12 & 33 & 11 & 31 & 12 & NS \\
\hline \multicolumn{8}{|l|}{ Fat } \\
\hline Intake $(\mathrm{g} / \mathrm{kg} /$ day $)$ & 5.81 & 1.29 & 6.40 & 1.56 & $\begin{array}{r}6.13 \\
92.1^{b}\end{array}$ & $\begin{array}{l}1.45 \\
46\end{array}$ & $<0.01$ \\
\hline Absorption (\% of intake) & $97.5^{\mathrm{a}}$ & 2.4 & $95.5^{\mathrm{a}, \mathrm{b}}$ & 2.4 & $92.1^{\mathrm{b}}$ & 4.6 & $<0.01$ \\
\hline
\end{tabular}

* There were 12 balance studies with each formula.

$\uparrow$ Values on same line with different superscripts are significantly $(p<0.05)$ different (Bonferroni $t$ test).

$\ddagger F$ test. 
absorption with increasing calcium concentration of formulas it is apparent that fractional calcium absorption tended to be greater during the second than during the first balance studies. This order effect was statistically significant overall $(p<0.05, \mathrm{~F}$ test), but was most pronounced with formula $\mathrm{MCa}$ (Fig. 3). The largest differences in fractional calcium absorption (18.3 and 14.9 percentage points, respectively), between the first and second study were observed in subjects 2492 and 2488 , for whom 4 wk elapsed between the first and second balance studies. The interaction term, formula $\times$ order, was not significant. A significant $(p<0.05)$ order effect was also found for fractional retention of calcium, but not for the other parameters of calcium balance. Figure 3 also indicates that subject 2492 behaved differently than the other five subjects. The performance of subject 2492 was therefore examined by a linear contrast procedure. Fecal excretion of calcium was found to be significantly $(p<$ 0.001 ) higher and absolute and fractional absorption significantly $(p<0.001)$ lower than in the other subjects. Although urinary excretion of calcium was less $(p<0.05)$ in subject 2492 , absolute and fractional retentions were still significantly $(p<0.001)$ less in this subject than in the other subjects.

Statistical analysis of the data for calcium was repeated with the data for subject 2492 excluded. The results were nearly the same.

The relation of net absorption to intake of calcium is presented in Figure 4. Excluding results for subject 2492, whose atypical performance is again evident, the relationship is strong ( $r=$ 0.904 ) and linear over the range of calcium intakes. The equation describing this relationship is presented in Table 4, along with equations describing the relationships of the other parameters of calcium balance to intake of calcium. Of note is the positive $y$ intercept of the regression of both absorption and retention on intake of calcium.

\section{DISCUSSION}

This study has shown that in normal infants increasing the intake of calcium is associated with decreased intestinal absorption of phosphorus and fat. No effect on absorption of copper, magnesium, or zinc was demonstrated. Increased intake of calcium was associated with greater absorption of calcium per unit of body weight but lesser absorption when expressed as percentage of intake. There were two unexpected, and still unexplained, findings: 1) net absorption of calcium was greater during the second than during the first of the two balance studies with at least one formula and 2) absorption of calcium and fat by one subject was consistently poor. The balanced cross-over design provided effective protection against confounding of results by

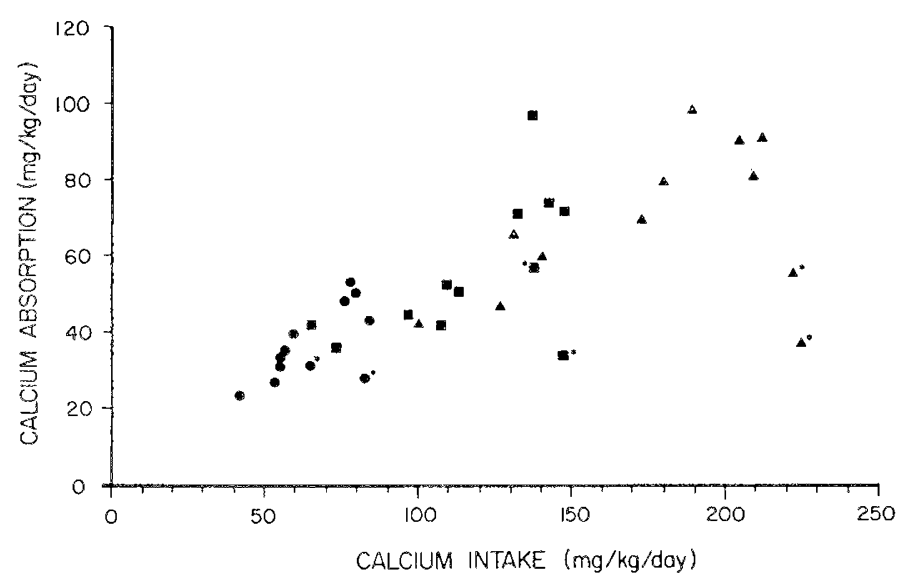

Fig. 4. Relation of absorption to intake of calcium. Symbols as in Figure 1. Each symbol represents the result of one balance study. Data for subject 2492 are indicated by an asterisk. Excluding data for subject 2492 , relation is described by: $y=0.373 x+13.2 ; r=0.904$.
Table 4. Relationship between intake of calcium $(x)$ and other parameters $(y)$ of calcium balance $(n=30$, excluding studies with subject 2492)

\begin{tabular}{llcc}
\hline \multicolumn{1}{c}{ Parameter $(\mathrm{y})$} & $\begin{array}{c}\text { Linear regression } \\
\text { equation }\end{array}$ & $r$ & $p$ \\
\hline $\begin{array}{l}\text { Urinary excretion }(\mathrm{mg} / \\
\mathrm{kg} / \text { day) }\end{array}$ & $\mathrm{y}=0.008 \mathrm{x}+1.8$ & 0.209 & $\mathrm{NS}$ \\
$\begin{array}{l}\text { Fecal excretion }(\mathrm{mg} / \mathrm{kg} / \\
\quad \mathrm{day})\end{array}$ & $\mathrm{y}=0.627 \mathrm{x}-13.2$ & 0.963 & $<0.001$ \\
Absorption $(\mathrm{mg} / \mathrm{kg} /$ day) & $\mathrm{y}=0.373 \mathrm{x}+13.2$ & 0.904 & $<0.001$ \\
Absorption $(\%$ of intake) & $\mathrm{y}=-0.112 \mathrm{x}+64.1$ & 0.585 & $<0.001$ \\
Retention $(\mathrm{mg} / \mathrm{kg} /$ day) & $\mathrm{y}=0.365 \mathrm{x}+11.3$ & 0.885 & $<0.001$ \\
Retention $(\%$ of intake) & $\mathrm{y}=-0.099 \mathrm{x}+59.9$ & 0.493 & $<0.01$ \\
\hline
\end{tabular}

these unexpected findings. It also provided protection against possible differences between subjects in vitamin $D$ status or in nutrient intake from nonformula sources, including water.

Soy protein isolate was chosen as the protein source because it afforded the required flexibility with regard to calcium content. With the exception of phosphorus, infants absorb minerals from soy isolate-based formulas at least as well as from milk-based formulas (42-44).

The main purpose of this study was to examine the effect of varying levels of dietary calcium on the absorption of other nutrients. In agreement with the literature, higher intakes of calcium were associated with decreased absorption of phosphorus and fat. In both cases the effect of dietary calcium was unequivocal and dose dependent. As already noted, absorption of phosphorus is decreased at high calcium intakes in animals (14) adult humans (5-7), and premature infants (8). The present findings thus confirm the literature and extend it to the normal term infant. The study also confirms the results of others (2-8) that urinary excretion of phosphorus decreases as absorption of phosphorus decreases. Because the decreased urinary excretion of phosphorus largely compensated for the decreased absorption, there was no net effect on phosphorus retention.

As noted, the depressant effect of high dietary calcium on absorption of fat has been recognized for many years $(8-14)$. Although statistically significant in the present study, the decrease in fat absorption at the higher calcium intake was not large enough to be of clinical significance. The fat mixture used was on the whole well absorbed. With less well absorbed fats, such as butterfat, the depression of absorption by high dietary calcium intake may be much greater $(13,14)$. Calcium most likely impairs fat absorption by inhibiting the partition of long-chain saturated fatty acids from the oil phase to the micellar phase (45).

No effects of calcium intake were observed on absorption of magnesium, copper, and zinc. In the case of magnesium and copper this was to be expected on the basis of available data (1, $19,20,23,24)$. Failure to demonstrate an antagonistic effect of high calcium intake on absorption of zinc, as has been reported in animals (15-18), may have been due to the experimental conditions. Whereas the animal studies have used marginal zinc intakes and large increases in calcium intake, the infants were evidently in satisfactory zinc nutritional status, and received an ample zinc intake and a rather modest increase in calcium intake. The conclusion from the present results is that calcium is unlikely to affect zinc absorption by infants under usual dietary conditions.

In interpreting the observed relationship between calcium intake and calcium absorption it is assumed that the infants were in adequate vitamin D status, on the basis of intakes of about 400 IU vitamin D daily since birth. However, documentation of vitamin $D$ status was not obtained. On the basis of animal and human studies it was anticipated that fractional absorption of calcium would be lower at high intakes than at low intakes. The results conform to the prediction, fractional calcium absorption decreasing from 57 to 47 to $39 \%$ of intake as calcium intake increased from low to high. It is possible that these changes in 
fractional calcium absorption were due to adaptive changes in the active, saturable transport component. However, examination of the relationship between calcium intake and absolute calcium absorption suggests a possible alternate explanation. The observed relationship (Fig. 4) was essentially linear with a positive $y$-intercept. When data were expressed as $\mathrm{mg} /$ day (rather than $\mathrm{mg} / \mathrm{kg} /$ day), the relationship (not shown) was similar, although at higher intakes of calcium, absorption tended to level off. This relationship is very similar to the linear portion of the curvilinear relationship observed between calcium absorption and intraluminal calcium concentration with the ligated loop method (32) or calcium concentration on the mucosal side with the everted sac technique (46). If this analogy is valid, the slope of the regression equation $(0.373)$ observed in the present study describes the nonsaturable component of calcium absorption, whereas the $y$ intercept (13.2) describes the saturable component. If this interpretation is correct, the present data suggest that there was either no adaptive change in the saturable component of calcium absorption or that a change, if present, was too small to be detectable. The literature provides little information regarding the time required for the response to take place and lack of an adaptive change might have been due to insufficient time for the response to occur. It is possible also that the dietary calcium levels used in the present study were not high enough to provoke adaptive down-regulation, and not low enough to provoke upregulation. However, we (unpublished observations) have found a linear relationship between absorption and intake of calcium even for a much wider range of intakes. Data from 174 balance studies in normal infants fed human milk, milk-based formulas, or whole cow milk, with intakes of calcium ranging from 15 to $390 \mathrm{mg} / \mathrm{kg} /$ day, showed a strong $(r=0.851, p<0.001)$ linear relationship described by the equation, absorption $=0.394 \times$ intake +1.2 (all values in $\mathrm{mg} / \mathrm{kg} /$ day).

The observed order effect on absorption of calcium and phosphorus (i.e. higher absorption during the second balance study than during the first) was most evident in studies with formula $\mathrm{MCa}$, the only formula that was at times fed for more than 11 days before the first balance period and for more than 25 days before the second balance period. It appears likely that intercurrent illnesses, responsible for the relatively long prebalance feeding intervals, were somehow responsible for the observed order effect, although it remains unclear whether the association resulted from the illnesses per se, or the prolonged prefeeding periods caused by the illnesses. In this context it may be relevant that we have previously observed (unpublished observations) temporarily depressed calcium absorption in infants experiencing minor febrile and afebrile illnesses. It appears unlikely that the order effect represents an adaptive response to the level of dietary calcium intake because, at least at the highest calcium intake, one would have expected a downward rather than an upward adjustment of calcium retention with the duration of feeding.

Subject 2492 was a healthy, thriving boy with no clinical evidence of gastrointestinal disease before or during the balance

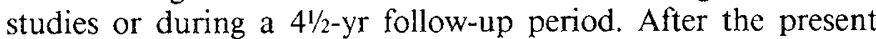
study, he continued to show poor absorption of calcium and fat in other balance studies. He was the youngest subject in the present study and although his calcium absorption increased with age, this can be explained by the progression from formula $\mathrm{LCa}$ to $\mathrm{MCa}$ to $\mathrm{HCa}$ (Fig. 3). We have not previously been able to demonstrate age-related changes in calcium absorption in fullterm infants (42; unpublished observations). In this study there was no age-effect when data for subject 2492 were excluded. Although absorption of calcium and fat were consistently lower in this subject than in the other five subjects, the absorption of other nutrients was not noticeably affected. Increased fecal excretion of fat (47-49) as well as impaired digestion of lactose (50, 51) have been shown to be associated with impaired absorption of calcium. However, if impaired absorption of fat or lactose had been the primary defect, one would have expected some recognizable clinical correlate and probably poor absorption of other nutrients. Although an age-effect or a primary defect of fat or lactose absorption cannot be ruled out, it appears that this infant may have had a primary defect of calcium absorption. The fact that absorption of calcium $(\mathrm{mg} / \mathrm{kg} / \mathrm{day})$ of this subject was very little influenced by the intake of calcium (Fig. 4) suggests that the defect was in the passive diffusive component rather than in the active, saturable component of calcium absorption.

\section{REFERENCES}

1. Clark I 1969 lmportance of dietary Ca:PO ratios on skeletal, $\mathrm{Ca}, \mathrm{Mg}$, and $\mathrm{PO}_{4}$ metabolism. Am J Physiol 217:865-870

2. Morgan DP, Young EP, Earle IP, Davey RJ, Stevenson JW 1969 Effects of dietary calcium and zinc on calcium, phosphorus and zinc retention in swine. J Anim Sci 29:900-905

3. Goto S, Sawamura T 1973 Effect of excess calcium intakes on absorption of nitrogen, phosphorus and calcium. Nutr Rep Int 7:103-110

4. Hurwitz S, Dubrov D, Eisner U, Risenfeld G, Bar A 1978 Phosphate absorption and excretion in the young turkey, as influenced by calcium intake. I Nutr 108:1329-1335

5. Leichsenring JM, Norris LM, Lamison SA 1951 The effect of level of intake on calcium and phosphorus metabolism in college women. J Nutr 45:407418

6. Spencer H, Osis D, Kramer L, Wiatrowski E, Norris C 1975 Effect of calcium and phosphorus on fluoride metabolism in man. $\mathrm{J}$ Nutr 105:733-740

7. Spencer H, Kramer L, Osis D, Norris C 1978 Effect of phosphorus on the absorption of calcium and on the calcium balance in man. J Nutr 108:447457

8. Day GM, Chance GW, Radde IC, Reilly BJ, Park E, Sheepers J 1975 Growth and mineral metabolism in very low birth weight infants. II. Effects of calcium supplementation on growth and divalent cations. Pediatr Res 9:568575

9. Miller ER, Ullrey DE, Zutaut CL, Baltzer BV, Schmidt DA, Hoefer JA, Luecke RW 1962 Calcium requirement of the baby pig. J Nutr 77:7-17

10. Goto S, Sugai T 1975 Effect of excess calcium intake on absorption of nitrogen, fat, phosphorus and calcium in adult rats. The use of organic calcium salt Nutr Rep Int 11:49-54

11. Lutwak L, Laster L, Gitelman HJ, Fox M, Whedon GD 1964 Effects of high dietary calcium and phosphorus on calcium, phosphorus, nitrogen and fat metabolism in children. Am J Clin Nutr 14:76-82

12. Katz L, Hamilton JR 1974 Fat absorption in infants of birth weight less than 1,300 gm. J Pediatr 85:608-614

13. Holt LE, Tidwell HC, Kirk CM, Cross DM, Neale S 1935 Studies in fat metabolism. I. Fat absorption in normal infants. J Pediatr 6:427-480

14. MacLaurin JC, Watson J, Murphy W, Stewart ME, Griffin JF, Samuel PD 1975 Fat, calcium and nitrogen balance in full-term infants. Postgrad Med J 51(suppl 3):45-51

15. Forbes RM 1960 Nutritional interactions of zinc and calcium. Fed Proc 19:643-647

16. Hoekstra WG 1966 Recent observations on mineral interrelationships. Fed Proc 23:1068-1076

17. Hsu FS, Krook L, Pond WG, Duncan JR 1975 Interactions of dietary calcium with toxic levels of lead and zinc in pigs. $J$ Nutr 105:112-118

18. Forbes RM, Erdman JW Jr, Parker HM, Kondo H, Ketelsen SM 1983 Bioavailability of zinc in coagulated soy protein (tofu) to rats and effect of dietary calcium at a constant phytate: zinc ratio. J Nutr 113:205-210

19. Wester PO 1974 Trace element balances in relation to variations in calcium intake. Atherosclerosis 20:207-215

20. Spencer H, Asmussen CR, Holtzman RB, Kramer L 1979 Metabolic balances of cadmium, copper, manganese, and zinc in man. Am J Clin Nutr 32:18671875

21. Snedeker SM, Smith SA, Greger JL 1982 Effect of dietary calcium and phosphorus levels on the utilization of iron, copper, and zinc by adult males. J Nutr 112:136-143

22. Steinhardt Bour NJ, Soullier BA, Zemel MB 1984 Effect of level and form of phosphorus and level of calcium intake on zinc, iron and copper bioavailability in man. Nutr Res 4:371-379

23. Underwood EJ 1977 Trace Elements in Human and Animal Nutrition. Academic Press, New York, pp 70-73

24. Norman DA, Fordtran JS, Brinkley LJ, Zerwekh JE, Nicar MJ, Strowig SM Pak CYC 1981 Jejunal and ileal adaptation to alterations in dietary calcium. J Clin Invest 67:1599-1603

25. Nicolaysen R, Eeg-Larsen N, Malm OJ 1953 Physiology of calcium metabolism. Physiol Rev 33:424-444

26. Kimberg DV, Schachter D, Schenker H 1961 Active transport of calcium by intestine: effects of dietary calcium. Am J Physiol 200:1256-1262

27. Zornitzer AE, Bronner F 1971 In situ studies of calcium absorption in rats. Am J Physiol 220:1261-1266

28. Kemm JR 1973 Effect of previous dietary history of calcium intake on the skeleton and calcium absorption in the rat. J Physiol 230:643-658

29. Krawitt EL Stubbert PA Ennis PH 1973 Calcium absorption and brush border phosphatases following dietary calcium restriction. Am J Physiol 224:548-551

30. Armbrecht HJ, Zenser TV, Bruns MEH, Davis BB 1979 Effect of age on intestinal calcium absorption and adaptation to dietary calcium. Am J 
Physiol 236:E769-E774

31. Armbrecht HJ, Zenser TV, Gross CJ, Davis BB 1980 Adaptation to dietary calcium and phosphorus restriction changes with age in the rat. Am J Physiol 239:E322-E327

32. Pansu D. Bellaton C, Bronner F 1981 Effect of $\mathrm{Ca}$ intake on saturable and nonsaturable components of duodenal Ca transport. Am J Physiol 240:G32G37

33. Edelstein S, Fullmer CS, Wasserman RH 1984 Gastrointestinal absorption of lead in chicks: involvement of the cholecalciferol endocrine system. J Nutr 114:692-700

34. Hove K 1984 Effects of $1 \alpha$-hydroxylated metabolites of cholecalciferol on intestinal radiocalcium absorption in goats. $\mathrm{Br} J$ Nutr 51:157-164

35. Spencer H, Lewin I. Fowler J, Samachson J 1969 Influence of dietary calcium intake on Ca absorption in man. Am J Med 46:197-205

36. Gallagher JC, Riggs BL, Eisman J, Hamstra A, Arnaud, SB, DeLuca HF 1979 Intestinal calcium absorption and serum vitamin $\mathrm{D}$ metabolites in normal subjects and osteoporotic patients. Effect of age and dietary calcium. $\mathbf{J} \mathbf{C l i n}$ Invest 64:729-736

37. Ribovich ML, DeLuca HF 1975 The influence of dietary calcium and phosphorus on intestinal calcium transport in rats given vitamin D metabolites. Arch Biochem Biophys 170:529-535

38. Fomon SJ 1974 Appendix IV: Collection of urine and feces and metabolic balance studies. In: Infant Nutrition, 2nd ed. WB Saunders, Philadelphia, pp 549-556

39. Van de Kamer JH, Ten Bokkel Huinink H, Weijers HA 1949 Rapid method for the determination of fat in feces. J Biol Chem 177:347-355

40. Fomon SJ. Thomas LN, Filer LJ Jr, Anderson TA, Bergmann KE 1973 Requirements for protein and essential amino acids in early infancy. Studies with a soy-isolate formula. Acta Paediatr Scand 62:33-54

41. Fiske CH, Subbarow Y 1925 The colorimetric determination of phosphorus. J
Biol Chem 66:375-400

42. Fomon SJ 1974 Major minerals. In: Infant Nutrition, 2nd ed. WB Saunders, Philadelphia, pp 271-276

43. Ziegler EE, Edwards BB, Jensen RL, Filer LJ, Jr., Fomon SJ 1978 Zinc balance studies in normal infants. In: Kirchgessner $M(e d)$ Trace Element Metabolism in Man and Animals. Institut für Ernährungsphysiologie, Freising-Weihenstephan, pp 292-295

44. Ziegler EE, Fomon SJ, Edwards BB, Nelson SE 1982 Mineral absorption from soy-based and milk-based infant formulas. Am J Clin Nutr 35:823(abstr)

45. Freeman CP 1969 Properties of fatty acids in dispersions of emulsified lipid and bile salt and the significance of these properties in fat absorption in the pig and the sheep. Br J Nutr 23:249-263

46. Ghishan FK, Parker P, Nichols S, Hoyumpa A 1984 Kinetics of intestinal calcium transport during maturation in rats. Pediatr Res 18:235-239

47. Agnew JE, Holdsworth CD 1971 The effect of fat on calcium absorption from a mixed meal in normal subjects, patients with malabsorptive disease, and patients with a partial gastrectomy. Gut 12:973-977

48. Kobayashi A, Utsunomiya T, Ohbe Y, Nagashima Y 1974 Intestinal absorption of calcium and magnesium in hepatobiliary disease in infancy. Arch Dis Child 49:90-96

49. Tantibhedhyangkul P, Hashim SA 1978 Medium-chain triglyceride feeding in premature infants: effects on calcium and magnesium absorption. Pediatrics 61:537-545

50. Condon JR, Nassim JR, Millard FJC, Hilbe A, Stainthorpe EM 1970 Calcium and phosphorus metabolism in relation to lactose tolerance. Lancet $1: 1027$ 1029

51. Kocián J, Skála I, Bakos K 1973 Calcium absorption from milk and lactosefree milk in healthy subjects and patients with lactose intolerance. Digestion $9: 317-324$

\title{
The Effect of Energy Intake and Expenditure on the Recovery of ${ }^{13} \mathrm{CO}_{2}$ in the Parenterally Fed Neonate during a 4-Hour Primed Constant Infusion of $\mathrm{NAH}^{13} \mathrm{CO}_{3}$
}

\author{
J. E. E. VAN AERDE, ${ }^{1}$ P. J. J. SAUER, P. B. PENCHARZ, U. CANAGARAYAR, J. BEESLEY, \\ J. M. SMITH, AND P. R. SWYER
}

Departments of Pediatrics, Medical Engineering, and Nutritional Sciences, University of Toronto and The Research Institute, The Hospital for Sick Children, Toronto, Ontario, Canada, M5G 1 X8

\begin{abstract}
The use of ${ }^{13} \mathrm{CO}_{2}$ excretion to measure the oxidation of ${ }^{13} \mathrm{CO}_{2}$ labeled substrates is increasing as it is both noninvasive and lacks the radiation exposure associated with the use of ${ }^{14} \mathrm{C}$. No standards are available for ${ }^{13} \mathrm{CO}_{2}$ recovery in breath from the bicarbonate pool in the neonate. A primed constant infusion of $\mathrm{NaH}^{13} \mathrm{CO}_{3}$ over 4 $h$ was used with open circuit indirect calorimetry in 15 appropriate for gestational age newborn infants (gestational age 28-39 wk; postnatal age $2-52$ days), on varying amounts of intravenous feeding $\left(37-114 \mathrm{kcal} \cdot \mathrm{kg}^{-1} \cdot \mathrm{day}^{-1}\right)$ Following a bolus of $6.9 \mu \mathrm{mol} \cdot \mathrm{kg}^{-1}$ of $\mathrm{NaH}^{13} \mathrm{CO}_{3}$, a main-
\end{abstract}

Received December 18, 1984; accepted March 13, 1985

Correspondence should be addressed to Paul B. Pencharz, M.B., Ph.D. F.R.C.P.(C). Head, Division of Clinical Nutrition, The Hospital for Sick Children 555 University Avenue. Toronto, Ontario, Canada, M5G 1 X8.

Supported in part by a grant from the Physicians Incorporated Foundation ( 84

18) and the Medical Research Council of Canada (MT-5466)

1 Research Fellow of The Hospital for Sick Children Foundation, Toronto, Ontario. tenance infusion of $4.6 \mu \mathrm{mol} \cdot \mathrm{kg}^{-1} \cdot \mathrm{h}^{-1}$ was started. The ${ }^{13} \mathrm{C}$ enrichment in breath rose rapidly to reach a plateau by 90 min with $<5 \%$ variation of the plateau. Recovery of the tracer in breath ranged from 69.6-83.5\% and was significantly correlated with 1$)$ energy intake (37-114 $\left.\left.\mathrm{kcal} \cdot \mathrm{kg}^{-1} \cdot \mathrm{day}^{-1}\right) ; 2\right)$ metabolic rate $\left(34.6-56.1 \mathrm{kcal} \cdot \mathrm{kg}^{-1}\right.$. day $\left.\left.^{-1}\right) ; 3\right) \mathrm{VCO}_{2}\left(4.86-7.43 \mathrm{ml} \cdot \mathrm{kg}^{-1} \cdot \mathrm{min}^{-1}\right)$. There was no correlation with the level of protein or fat intake. We provide an equation that can be used to calculate the correction factor when doing constant infusion substrate oxidation studies with a ${ }^{13} \mathrm{C}$ label in neonates. (Pediatr Res 19:806-810, 1985)

\section{Abbreviations}

$\dot{\mathrm{V}} \mathrm{CO}_{2}$, total carbon dioxide production APE, atom percent excess iv, intravenous 